\title{
SEBARAN DAN KEPADATAN UDANG MANTIS (Carinosquilla spinosa) DI PERAIRAN ARAFURA
}

\author{
Wedjatmiko \\ Peneliti pada Balai Riset Perikanan Laut, Muara Baru-Jakarta \\ Komplek Pelabuhan Perikanan Samudera Jl. Muara Baru Ujung-Jakarta 14440, E-mail: kanlutmb@indosat.net.id
}

\begin{abstract}
ABSTRAK
Udang mantis (Carinosquilla spinosa) merupakan salah satu komoditas perikanan laut dan termasuk dalam jenis udang, dengan ordo Stomatopoda. Secara umum, komoditas tersebut sering disebut dengan udang ronggeng, udang mantis, dan udang pengko. Penelitian terhadap penyebaran dan densitas udang mantis (Carinosquilla spinosa) di perairan Arafura dilaksanakan pada bulan Oktober sampai dengan Nopember 2003. Alat tangkap yang digunakan dalam penelitian ini adalah jenis alat tangkap khusus untuk udang komersial (traw/). Lokasi penelitian difokuskan di sekitar muara Sungai Digul dengan kordinat $6^{\circ}-7,5^{\circ}$ LS dan $137^{\circ}-138^{\circ}$ BT, yang merupakan daerah penangkapan udang komersial. Hasil penelitian menunjukkan bahwa penyebaran udang mantis terdapat di semua stasiun penelitian, dengan dominasi hasil tangkapan tepat di depan muara Sungai Digul, dengan densitas sekitar 28,75 sampai dengan 51,50 kg per jam. Sedangkan rata-rata hasil tangkapan udang mantis di perairan Arafura adalah $14 \mathrm{~kg}$ per jam. Ukuran panjang rata-rata udang mantis secara total adalah $11,00 \mathrm{~cm}$ dengan bobot rata-rata per ekor 20,83 g dari kisaran 6,1 sampai dengan 25,0 $\mathrm{cm}$. Modus kelas frekuensi panjang terjadi pada ukuran 9,1 sampai dengan $10 \mathrm{~cm}$.
\end{abstract}

KATA KUNCI: $\quad$ kepadatan, udang mantis, Carinosquilla spinosa, sumber daya, perairan Arafura

ABSTRACT: Distribution and density of mantis shrimp (Carinosquilla spinosa) in Arafura waters. By: Wedjatmiko

Mantis shrimp (Carinosquilla spinosa) is one of marine fisheries commodity and includes in crustaceans. In generally this shrimp is called udang ronggeng or udang pengko (local named). Research on mantis shrimp (Carinosquilla spinosa) resources in Arafura waters was conducted during October to November 2003. The fishing gear used was stern trawl with length of head rope $35 \mathrm{~m}$ and ground rope $41 \mathrm{~m}$. Research location in Arafura waters, was conducted closed to comercial shrimp catch area by cordinat $6^{\circ}-7,5^{\circ} \mathrm{S}$ dan $137^{\circ}-138^{\circ} \mathrm{E}$. Result of the research shows that distribution of the shrimp was on whole station, but dominan density was closed to Digul Estuary, with catch rate 28,75 to $51,50 \mathrm{~kg}$ per hour. The average catch rate every station was $14 \mathrm{~kg}$ per hour and the size 11,00 cm and 20,83 g. Minimum size of mantis shrimp was 6,1 cm, and maximum size was $25 \mathrm{~cm}$.

KEYWORDS: density, mantis, shrimp, Carinosquilla spinosa, resources, Arafura waters

\section{PENDAHULUAN}

Udang Mantis (Carinosquilla spinosa) adalah salah satu spesies dari Squilla yang banyak tertangkap di perairan Arafura. Squilla yang merupakan salah satu komoditas perikanan laut dan termasuk dalam jenis udang, dengan ordo Stomatopoda. Secara umum, komoditas tersebut sering disebut dengan udang ronggeng, udang mantis, udang pengko (Nontji, 1987), sedangkan di Sulawesi Selatan jenis udang tersebut dikenal dengan nama udang nenek, udang getak, atau doang latta (Mansyur, 1999). Udang jenis ini sangat diminati oleh konsumen luar negeri seperti Hongkong, Taiwan, dan Jepang. Beberapa aspek diminati udang jenis ini, di samping rasa yang cukup disenangi (lezat), juga disebabkan oleh mitos Cina yang mengatakan bahwa jenis udang tersebut mengandung banyak hormon yang dapat menyebabkan tetap awet muda serta menjadi obat kuat.

Di Indonesia, khusus di kawasan Indonesia bagian barat sudah banyak penduduk mengkonsumsi udang jenis Squilla ini, baik oleh kalangan nelayan maupun oleh warga negara keturunan yang meyakini akan mitos tersebut. Oleh karena itu, udang jenis Squilla di Indonesia sudah diperdagangkan baik untuk konsumsi domestik maupun untuk komoditas ekspor. Sementara itu, di kawasan Indonesia bagian timur belum ada yang memanfaatkan jenis udang tersebut. Harga udang mantis (Squilla) di wilayah Indonesia bagian barat, khusus di daerah Jambi pada tahun 1997 untuk udang ukuran $19 \mathrm{~cm}$ Rp.500,- per ekor, sedangkan untuk ukuran $24 \mathrm{~cm}$ atau lebih harga udang mencapai Rp.12.000,- per ekor (Syahasta \& Zarochman, 1998). 
Udang Mantis merupakan salah satu jenis krustasea yang salah satu umbai mulutnya berkembang dan berubah menjadi kaki perangkap yang panjang, berfungsi untuk memegang, dan merobek mangsa. Perubahan organ tersebut cukup panjang sehingga mirip dengan belalang sembah, oleh karena itu udang tersebut juga sering disebut dengan udang belalang. Dari studi pustaka diperoleh informasi bahwa jenis udang mantis di perairan Arafura menurut diidentifikasi sebagai Carinosquilla spinosa (Ahyong \& Naiyaneter, 1998).

\section{BAHAN DAN METODE}

Data yang di analisis merupakan sebagian hasil penelitian yang dilakukan pada bulan Oktober sampai dengan Nopember 2003, dengan kapal penelitian KM. Madidihang 02 (160 GT). Lokasi penelitian yang disurvei adalah perairan Arafura pada posisi $6^{\circ}-7,5^{\circ} \mathrm{LS}$ dan $137^{\circ}-138^{\circ}$ BT (Gambar 1).

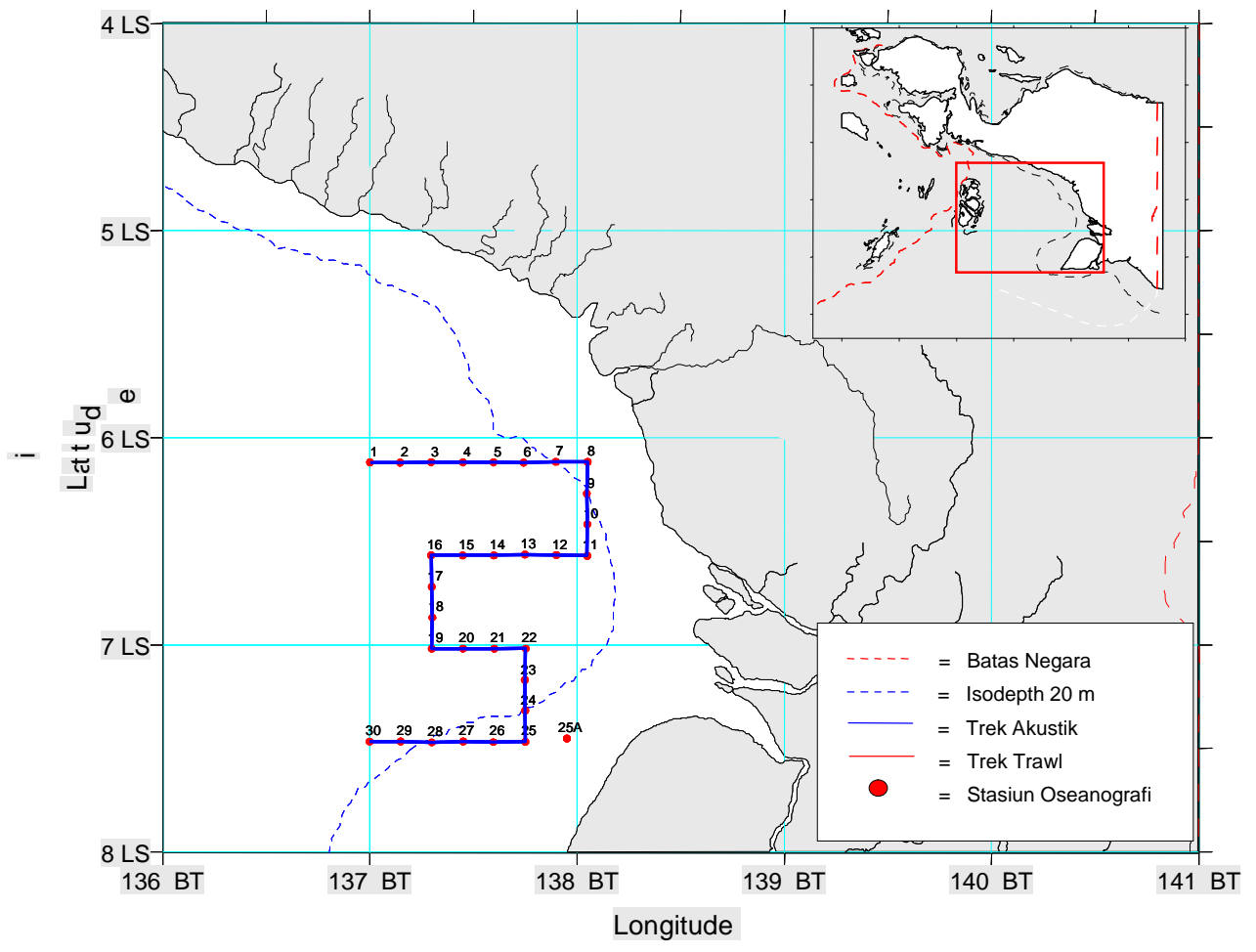

Gambar 1. Lokasi pengambilan contoh penelitian di perairan Arafura.

Figure 1. Sampling station in the Arafura Sea.

Alat tangkap yang digunakan adalah Thailand stern traw/yang dimodifikasi menjadi alat tangkap udang dan ikan demersal, dengan panjang head rope $35 \mathrm{~m}$, dan ground rope $41 \mathrm{~m}$. Outer board yang digunakan terbuat dari besi dengan ukuran $1,5 \times 2,0 \mathrm{~m}$, dan jaring terbuat dari bahan poly ethylin, rancang bangun trawl yang digunakan untuk pengambilan contoh adalah seperti pada Gambar 2. 

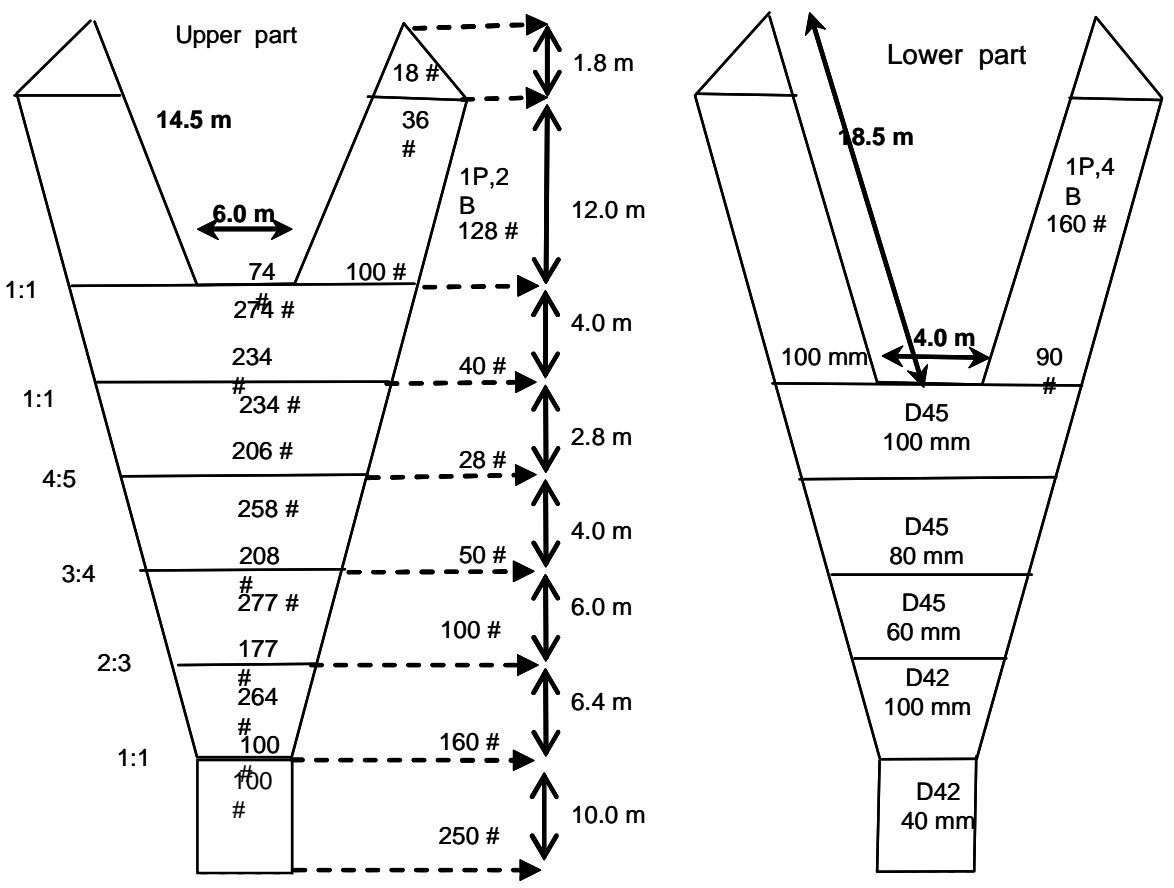

Gambar 2. Ukuran dan lay out jaring yang diginakan.

Figure 2. Design and lay out of shrimp trawl used.

Identifikasi dan analisis hasil tangkapan trawl tersebut, digunakan bantuan buku identifikasi ikan De Bruen et al. (1994); Allen (1999); Kailola \& Tarp (1993); Ahyong \& Naiyaneter (1998).

Perhitungan laju tangkap dan kepadatan stok ikan digunakan metode sapuan (swept area method) berdasarkan pada luas lahan yang diliput, kecepatan kapal waktu menarik jaring, lebar bukaan mulut jaring, dan hasil tangkapan (Sparre \& Venema, 1992) sebagai berikut:

$$
D=(1 / a \cdot n) \times(C / f)
$$

Keterangan/Remarks:

a.n=t.v.h.e $1,852 \cdot 0,001$

\section{di mana:}
a.n = panjang jalur yang dilalui jaring $(\mathrm{km})$
$\mathrm{C}=$ hasil tangkapan ( $\mathrm{kg}$ per jam)
$\mathrm{D}=$ kepadatan stok

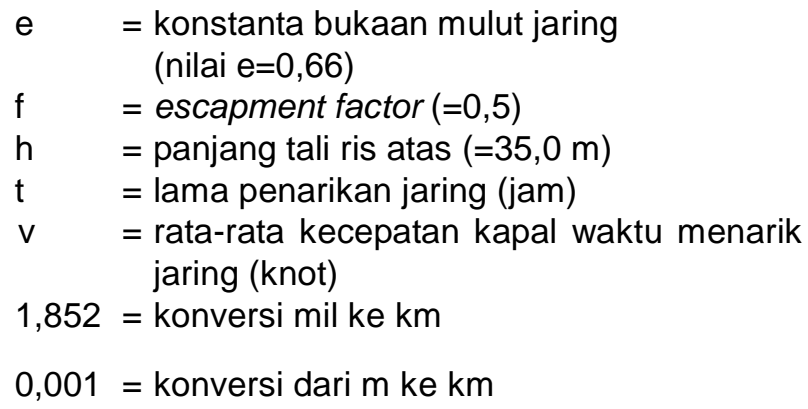

\section{Sebaran dan Densitas Sumber Daya}

Penyebaran sumber daya udang mantis di perairan Arafura berdasarkan pada hasil penelitian tahun 2003, yang pengambilan contoh menggunakan jaring udang (trawl), menunjukkan bahwa setiap stasiun trawl pengambilan contoh, selalu tertangkap udang mantis Carinosquilla spinosa (Gambar 3). 


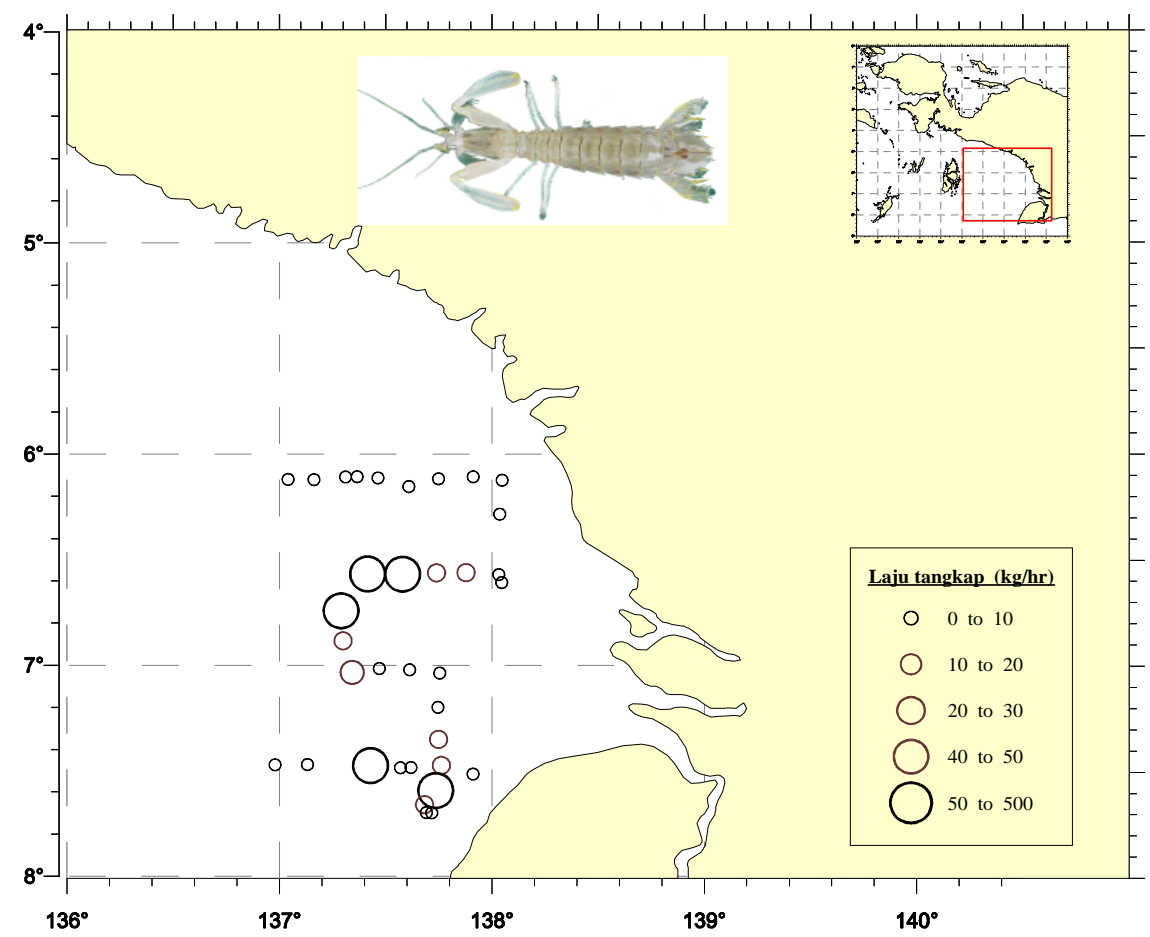

Gambar 3. Distribusi hasil tangkapan Carinosquilla spinosa di perairan Arafura. Figure 3. Catch distribution of Carinosquilla spinosa in the Arafura sea.

Sumber daya udang mantis berdasarkan pada total hasil tangkapan dan sebaran (Gambar 3), terlihat bahwa udang mantis (Carinosquilla spinosa) tertangkap di seluruh stasiun pengambilan contoh di perairan Arafura tersebut, hasil tangkapan paling banyak (dominan) terdapat di perairan sekitar muara Sungai Digul, pada koordinat 6,5 sampai dengan 7,0 LS dan 137,3 sampai dengan 137,8 BT. Sedangkan di lokasi lain volume hasil tangkapan Squilla relatif kecil. Dominasi hasil tangkapan udang mantis yang terletak di perairan depan muara Sungai Digul tersebut, erat kaitan dengan banyak armada penangkapan udang komersil yang pada waktu penelitian berlangsung, terkonsentrasi di wilayah perairan tersebut. Pada penangkapan udang komersial volume hasil tangkapan yang dimanfaatkan adalah sangat sedikit yaitu hanya 10\% (Allsops, 1982), sedangkan yang $90 \%$ dibuang kembali ke laut sebagai by catch. Udang mantis (Squilla) adalah termasuk komoditas yang tidak dimanfaatkan dalam penangkapan udang komersil atau termasuk salah satu species by catch. Ada kecenderungan semakin banyak by catch semakin besar hasil tangkapan udang mantis tersebut. Selama pengamatan pada penelitian ini terlihat bahwa udang mantis merupakan komoditas perikanan yang tahan hidup pada saat trawling, dan pada saat by catch secara keseluruhan dibuang kembali ke laut, udang mantis dalam keadaan hidup bersama jenis krustasea lain (kepiting).

\section{Habitat}

Hasil pengamatan terhadap kondisi lingkungan hidup diperoleh informasi bahwa substrat dasar perairan (habitat) sebagian besar stasiun didominasi oleh tipe sedimen berliat. Secara keseluruhan, hasil pengamatan substrat dasar diperoleh 3 tekstur substrat, yaitu pasir, debu atau lumpur, dan liat. Pengelompokan partikel substrat menurut Shepard, (1954) adalah pasir (ukuran 0,075 sampai dengan $0,8 \mathrm{~mm}$ ), debu atau lumpur (ukuran $0,053 \mathrm{~mm}$ ), dan liat (ukuran $<0,053 \mathrm{~mm}$ ) di mana masing-masing stasiun menunjukkan komposisi yang bervariasi. Tampak bahwa sebagian besar stasiun didominasi oleh tipe sedimen berliat, liat berpasir, dan sebagian kecil pasir dan lempung. Menurut Odum (1971); Davies (1980); Krumbein \& Sloss (1963), sedimen dasar perairan berasal dari aliran sungai yang membawa partikel-partikel lumpur dan mengendap di dasar perairan laut membentuk tipe sedimen tertentu. Tipe sedimen ditentukan oleh kekuatan ombak dan arus di laut, bila arus kuat maka partikel-partikel yang mengendap ukuran relatif lebih besar, keadaan sebaliknya bila kondisi arus lemah. Hasil pengukuran arus di lokasi penelitian menunjukkan kecepatan relatif lemah, rata-rata $0,41 \mathrm{~m}$ per $\mathrm{dt}$, sedangkan tekstur liat yang diamati mempunyai ukuran butiran paling halus. Dengan demikian, dapat dikatakan bahwa di perairan ini telah terjadi pengendapan liat yang diduga berasal 
dari sungai-sungai yang bermuara di sekitar peraiaran Arafura, terutama Sungai Digul. Oleh karena itu, dapat dikatakan bahwa kondisi substrat dasar perairan berupa liat berpasir adalah merupakan habitat hidup bagi udang mantis.

Hasil pengamatan terhadap kualitas perairan di sekitar dasar termasuk rendah dan ada indikasi telah tercemar. Kandungan oksigen terlarut sangat rendah (kurang dari 2 ppm), suhu air berkisar 23,05 sampai dengan $24,96^{\circ} \mathrm{C}$, salinitas 34,58 sampai dengan $35,19^{\circ}$ / ${ }_{00}, \mathrm{pH} 7,22$ sampai dengan 7,74; dan kecepatan arus lemah berkisar 0,14 sampai dengan 0,70 m per dt. Kondisi kualitas perairan tersebut, memberikan informasi bahwa udang mantis (Carinosquilla spinosa) dapat hidup pada kondisi lingkungan dengan kualitas perairan yang sangat rendah.

\section{Volume Hasil Tangkapan}

Berdasarkan pada komposisi total hasil tangkapan, diperoleh bahwa udang mantis (Squilla), menduduki urutan ke-4 dari 60 famili yang dijumpai (Lampiran 1). Jenis ikan yang paling banyak dijumpai adalah ikan gulamah (Scianidae) 38\%, yang diikuti oleh kepiting dan rajungan (32\%), ikan lidah (Cynoglossidae) 6,4\%, dan urutan ke-4 adalah udang mantis yang sebagian besar adalah Carinosquilla spinosa 2,6\%. Rata-rata volume laju tangkap udang mantis tersebut adalah 14,3 kg per stasiun. Komposisi hasil tangkapan trawlyang dominan di perairan Arafura disajikan pada Gambar 4.

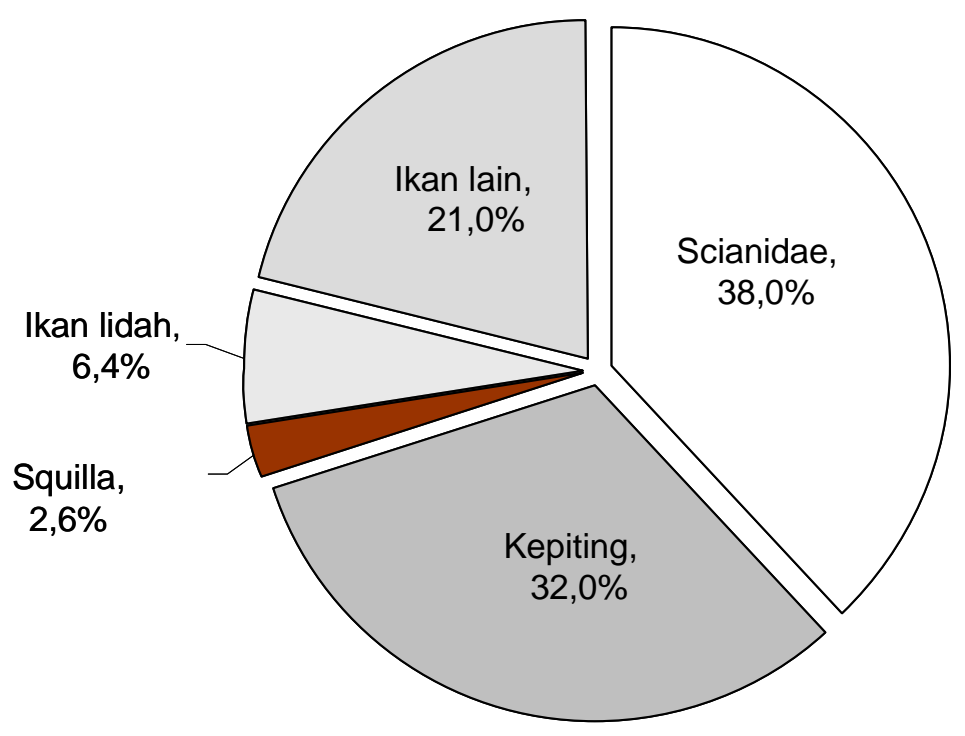

Gambar 4. Komposisi hasil tangkapan di Laut Arafura, tahun 2003. Figure 4. Catch composition in the Arafura sea, 2003.

Udang mantis yang tertangkap diambil contoh 247 ekor untuk diukur kelas panjang, dari hasil pengukuran terlihat modus kelas frekuensi panjang pada ukuran 9,5 $\mathrm{cm}$, ukuran terkecil pada kelas $4,5 \mathrm{~cm}$, dan ukuran terbesar pada kelas $24,5 \mathrm{~cm}$. Panjang rata-rata udang mantis secara total adalah $11,00 \mathrm{~cm}$ dengan bobot ratarata per ekor 20,83 g. Berdasarkan pada pola sebaran kelas frekuensi panjang terlihat ada 2 kelompok ukuran yang identik dengan umur dari udang mantis tersebut. Kedua kelompok tersebut mempunyai pola distribusi yang normal (Gambar 5). Terjadi dominasi kelompok umur tersebut juga dapat menunjukkan bahwa pemijahan atau perkembangan udang mantis tidak di pengaruhi oleh musim. Udang mantis di perairan Arafura dapat berkembang biak setiap saat. 


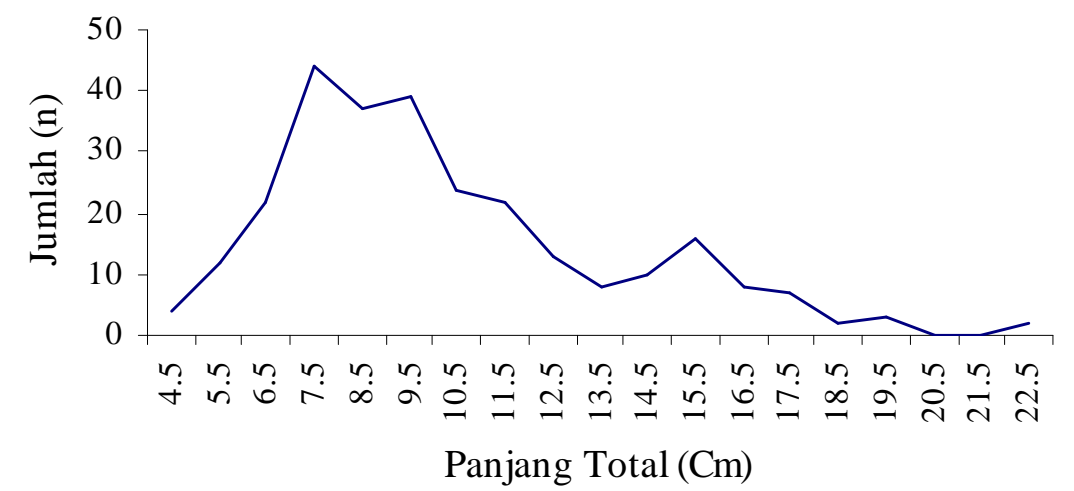

Gambar 5. Frekuensi panjang Carinosquilla spinosa di perairan Arafura.

Figure 5. Length frequency Carinosquilla spinosa in Arafura waters.

Ukuran udang mantis yang mempunyai nilai ekonomis tinggi adalah kelompok ukuran di atas $20 \mathrm{~cm}$. Hasil tangkapan udang mantis di perairan Arafura termasuk udang mantis yang mempunyai nilai ekonomis tinggi $(>20 \mathrm{~cm})$, namun volume kecil, sebagian besar ukuran udang mantis yang tertangkap belum mencapai ukuran ekonomis tinggi (7,5 sampai dengan $9,5 \mathrm{~cm})$. Besar volume udang mantis yang berukuran kecil (non ekonomis) dapat disebabkan oleh tinggi eksploitasi sumber daya perairan menggunakan alat tangkap trawl. Walaupun udang mantis di perairan Arafura bukan menjadi sasaran utama dalam eksplotasi sumber daya menggunakan alat tangkap trawl, namun udang mantis tersebut tertangkap oleh trawl. Sehingga sebaran populasi udang mantis juga dapat terganggu akibat tinggi operasional traw/ dalam eksplotasi sumber daya.

\section{KESIMPULAN}

1. Berdasarkan pada hasil penelitian tersebut dapat disimpulkan bahwa, prospek perikanan udang mantis (Carinosquilla spinosa) di perairan Arafura mempunyai peluang cukup besar, karena udang mantis (Carinosquilla spinosa) mempunyai nilai ekonomis cukup tinggi dan peluang untuk ekspor.

2. Penyebaran sumber daya hampir dijumpai merata di seluruh perairan Arafura, khusus untuk daerah penangkapan udang (traw).

3. Udang mantis di perairan Arafura mampu hidup pada kualitas perairan yang sangat rendah dengan kandungan oksigen terlarut kurang dari 2 ppm. Sementara itu, kualitas air yang lain adalah suhu berkisar 23,05 sampai dengan $24,96^{\circ} \mathrm{C}$, salinitas
34,58 sampai dengan $35,19 \%$, $\mathrm{pH} 7,22$ sampai dengan 7,74; dan kecepatan arus lemah berkisar 0,14 sampai dengan $0,70 \mathrm{~m}$ per dt. Substrat dasar perairan udang mantis didominasi oleh tipe sedimen liat dan liat berpasir.

4. Volume hasil tangkapan udang mantis di perairan Arafura cukup tinggi, di mana udang mantis menduduki urutan ke-4 dari total hasil tangkapan menggunakan alat tangkap trawl.

\section{Persantunan \\ Hasil dari kegiatan riset: Arafura T.A. 2002-2003 di Balai Riset Perikanan Laut}

\section{DAFTAR PUSTAKA}

Ahyong, S. \& P. Naiyaneter. 1998. Stomatopod crustaceans from Phuket and the Andaman Sea. Proceeding of the International Workshop on the Crustacea of the Andaman Sea. Phuket Marine Biological Center Departement of Fisheries. Thailand.

Allen, G. 1999. Marine fishes of South-East Asia. A field guide for anglers and divers. Western Australian Museum.

Allsopp, W. H. L. 1982. Use of fish by catch from shrimp trawling: Future development. In fish by catch bonus from the sea: Report of a technical consultation on shrimp by catch utilization held in Georgetown. Guyana. 27-30 October 1981. Ottawa. Ont. IDRC: 29-50. 
Davies, J. L. 1980. Geographical variation in coastal development. Lowe \& Brydone Printers Limited. The Ford. Nort Folk: 212 pp.

De Bruin, G. H. P., Russel, B. C., \& Bogusch, A. 1994. The marine fishery resources of Srillanka. FAO species identification field guid for fishery purpose. FAO. Rome.

Kailola, P. J. \& Tarp, T. G. 1993. Trawled fishes of Southern Indonesia and Northwestern Australia. Australian Development Assistance Bereau. Directorat General of fisheries-Indonesia. German Agency for Technical Cooperation.

Krumbein, W. C. \& L. L. Sloss. 1963. Stratigraphy and sedimentation. M. H. Freemen and Company. San Fransisco. $460 \mathrm{pp}$.

Mansyur, A. 1999. Mengenal udang mantis sebagai upaya menggali potensi pangan baru. Warta Penelitian Perikanan Indonesia. Jakarta.
Nontji, A. 1987. Laut Nusantara. Penerbit Jembatan. Jakarta. 368 hal.

Odum, E. P. 1971. Fundamental of ecology. $3^{\text {rd }}$ Edition. W. B. Sounders Comp. Phildelphia. 574 hal.

Shepard, F. P. 1954. Nomenclature based on sand silt clay rations. Journal Sediment Petrology. 24: 151158.

Sparre, P. \& S. C. Venema. 1992. Introduction to tropical fish stock assessment. Part 1. Manual. FAO Fish. Tech. Pap. (306/1) Rev. 1: 376.

Sumiono, B., Sudjianto,Y. Soselisa, \& T. S. Murtoyo. 2002. Laju tangkap dan komposisi jenis ikan demersal dan udang yang tertangkap trawl pada musim timur di perairan utara Jawa Tengah. Bali Penelitian Perikanan Laut. Jakarta.

Syahasta, D. G. \& Zarochman. 1998. Penangkapan udang mantis sebagai peluang bisnis ekspor. Jurnal Arrioma. Balai Pengembangan Penangkapan Ikan Semarang. (8): 1-24.

Diterima tanggal: 13 Januari 2005

Diterima setelah perbaikan tanggal: 25 Pebruari 2005

Disetujui terbit tanggal: 24 April 2006 
Lampiran 1. Total hasil tangkapan di perairan Arafura, tahun 2003

Appendix 1. Total of catch in Arafura waters, in 2003

\begin{tabular}{|c|c|c|c|c|}
\hline No. & Famili/Family & Jumlah/Amount (kg) & $\begin{array}{c}\text { Rata-rata/ } \\
\text { Average }\end{array}$ & (\%) \\
\hline 1 & Scianidae & $7.494,15$ & 208,17 & 38,47 \\
\hline 2 & Crabs/portunidae & $6.236,89$ & 173,24 & 32,02 \\
\hline 3 & Cynoglossidae & $1.261,41$ & 35,03 & 6,47 \\
\hline 4 & Squilla & 514,97 & 14,30 & 2,64 \\
\hline 5 & Holothuriidae & 475,26 & 13,20 & 2,44 \\
\hline 6 & Mollusca & 395,20 & 10,97 & 2,02 \\
\hline 7 & Harpodontidae & 305,95 & 8,49 & 1,57 \\
\hline 8 & Penaeidae & 232,41 & 6,45 & 1,19 \\
\hline 9 & Plotosidae & 222,06 & 6,16 & 1,14 \\
\hline 10 & Squids/sepiolidae & 182,46 & 5,06 & 0,93 \\
\hline 11 & Nemipteridae & 160,82 & 4,46 & 0,82 \\
\hline 12 & Pomadasyidae & 160,82 & 4,46 & 0,82 \\
\hline 13 & Clupeidae & 160,45 & 4,45 & 0,82 \\
\hline 14 & Dasyatididae & 154,72 & 4,29 & 0,79 \\
\hline 15 & Apogonidae & 145,22 & 4,03 & 0,74 \\
\hline 16 & Synodontidae & 141,58 & 3,93 & 0,72 \\
\hline 17 & Trichiuridae & 125,82 & 3,49 & 0,64 \\
\hline 18 & Serranidae & 97,51 & 2,70 & 0,50 \\
\hline 19 & Leiognathidae & 91,89 & 2,55 & 0,47 \\
\hline 20 & Platycephalidae & 86,03 & 2,39 & 0,44 \\
\hline 21 & Engraulidae & 77,92 & 2,16 & 0,40 \\
\hline 22 & Priacacthidae & 73,99 & 2,05 & 0,38 \\
\hline 23 & Cuttles/sepiidae & 58,47 & 1,62 & 0,30 \\
\hline 24 & Psettodidae & 53,98 & 1,49 & 0,27 \\
\hline 25 & Carangidae & 47,13 & 1,30 & 0,24 \\
\hline 26 & Polynemidae & 45,48 & 1,26 & 0,23 \\
\hline 27 & Mullidae & 44,57 & 1,23 & 0,22 \\
\hline 28 & Balistidae & 42,55 & 1,18 & 0,21 \\
\hline 29 & Tetraodontidae & 40,45 & 1,12 & 0,20 \\
\hline 30 & Opistognathidae & 40,40 & 1,12 & 0,20 \\
\hline 31 & Triacanthidae & 37,85 & 1,05 & 0,19 \\
\hline 32 & Carcharhinidae & 31,24 & 0,86 & 0,16 \\
\hline 33 & Muraenesocidae & 30,80 & 0,85 & 0,15 \\
\hline 34 & Soleidae & 30,60 & 0,85 & 0,15 \\
\hline 35 & Triglidae & 29,60 & 0,82 & 0,15 \\
\hline 36 & Rhinoprenidae & 24,01 & 0,66 & 0,12 \\
\hline 37 & Ariommatidae & 23,10 & 0,64 & 0,11 \\
\hline 38 & Theraponidae & 20,20 & 0,56 & 0,10 \\
\hline 39 & Lutjanidae & 12,15 & 0,33 & 0,06 \\
\hline 40 & Bothidae & 10,70 & 0,29 & 0,05 \\
\hline
\end{tabular}


Lampiran 1. Lanjutan

Appendix 1. Continue

\begin{tabular}{clccc}
\hline No. & Famili/Family & Jumlah/Amount $\mathbf{( k g )}$ & $\begin{array}{c}\text { Rata-rata/ } \\
\text { Average }\end{array}$ & (\%) \\
\hline 41 & Gobiidae & 9,55 & 0,26 & 0,04 \\
42 & Scaridae & 8,00 & 0,22 & 0,04 \\
43 & Scorpaenidae & 6,94 & 0,19 & 0,03 \\
44 & Labridae & 5,35 & 0,14 & 0,02 \\
45 & Ariidae & 4,25 & 0,11 & 0,02 \\
46 & Drepanidae & 4,00 & 0,11 & 0,02 \\
47 & Scombridae & 3,35 & 0,09 & 0,01 \\
48 & Scyllaridae & 3,05 & 0,08 & 0,01 \\
49 & Otherfood fish & 2,57 & 0,07 & 0,01 \\
50 & Ephippidae & 1,20 & 0,03 & 0,006 \\
51 & Plotocidae & 1,15 & 0,03 & 0,006 \\
52 & Rachycentridae & 1,00 & 0,02 & 0,005 \\
53 & Siganidae & 0,97 & 0,02 & 0,005 \\
54 & Gobiodidae & 0,95 & 0,02 & 0,005 \\
55 & Gobeidae & 0,02 & 0,005 \\
56 & Gymnuridae & 0,95 & 0,02 & 0,005 \\
57 & Pentapodidae & 0,90 & 0,02 & 0,004 \\
58 & Lethrinidae & 0,75 & 0,01 & 0,002 \\
59 & Gobeididae & 0,40 & 0,00 & 0,002 \\
60 & Diodontidae & 0,30 & 0,00 & 0,001 \\
\hline
\end{tabular}

